\title{
PENGARUH KUALITAS PELAYANAN, HARGA DAN PROMOSI TERHADAP KEPUASAN PELANGGAN SOWE BISTRO MEDAN
}

\author{
Andriasan Sudarso \\ Program Studi Manajemen Sekolah Tinggi Ilmu Ekonomi IBBI Medan \\ Corespondence Author : andriasans@gmail.com \\ Mulia Tamrin \\ Program Studi Manajemen Sekolah Tinggi Ilmu Ekonomi IBBI Medan \\ Chensiong80@yahoo.com
}

\begin{abstract}
ABSTRAK
Penelitian ini bertujuan untuk mengetahui pengaruh kualitas pelayanan, harga dan promosi terhadap kepuasan pelanggan Sowe Bistro Medan. Penelitian ini menggunakan metode penelitian deskriptif kuantitatif. Populasi dalam penelitian ini adalah pelanggan yang datang ke Sowe Bistro Medan selama dari bulan Januari 2016 sampai dengan Maret 2016 yang berjumlah 5.274 orang dan sampel penelitian 99 orang dengan rumus Slovin. Teknik analisa data menggunakan uji asumsi klasik, analisis regresi linear berganda, uji f, uji t dan koefisien determinasi.Hasil penelitian menunjukkan bahwa secara parsial, kualitas pelayanan, harga dan promosi berpengaruh terhadap kepuasan pelanggan. Secara simultan, bahwa kualitas pelayanan, harga dan promosi berpengaruh terhadap kepuasan pelanggan. Besarnya koefisien determinasi sebesar 0,792 artinya kemampuan variabel kualitas pelayanan, harga dan promosi menjelaskan pengaruhnya terhadap variabel kepuasan pelanggan sebesar $79,2 \%$. Sedangkan sisanya sebesar 20,8\% merupakan variabel bebas lain yang tidak diteliti dalam penelitian ini seperti periklanan, lokasi dan merek.
\end{abstract}

\section{Kata Kunci : Kualitas Pelayanan, Harga, Promosi, Kepuasan Pelanggan}




\section{PENDAHULUAN}

Era globalisasi ini, jumlah merek dan produk yang bersaing dalam pasar yang sangat banyak menyebabkan terjadinya persaingan usaha, dimana hal tersebut menuntut para pelaku bisnis untuk berusaha memberi kepuasan pada pelanggan melalui pelayanan yang baik berdasarkan merek atau produk yang dipasarkan.

Kualitas pelayanan merupakan suatu bentuk penilaian konsumen terhadap tingkat layanan yang diterima (perceived service) dengan tingkat layanan yang diharapkan (expected service). Agar dapat bersaing, bertahan hidup, dan berkembang, maka perusahaan dituntut untuk mampu memenuhi kebutuhan dan keinginan pelanggan dengan memberikan pelayanan yang terbaik dan berkualitas, maka dengan begitu pelanggan akan merasa mendapat kepuasan tersendiri dan merasa dihargai sehingga mereka senang dan bersedia untuk menjadi pelanggan tetap. Berdasarkan pra penelitian di Sowe Bistro Medan bahwa fenomena kualitas pelayanan yang terjadi dikarenakan Sowe Bistro Medan memiliki lahan parkir yang sempit sehingga pelanggan merasa tidak puas dengan memilih cafe lain, karyawan kurang cepat dan handal dalam melayani pelanggan sehingga karyawan tidak tertarik memesan lagi makanan dan minuman di Sowe Bistro Medan dan masih ada karyawan kurang ramah dan sopan terhadap konsumen sehingga pelanggan tidak menjadi Sowe Bistro Medan sebagai pilihan pertama.

Faktor harga adalah satu-satunya unsur dalam berbagai unsur bauran pemasaran eceran tersebut yang akan mendatangkan laba bagi peritel. Dalam iklim persaingan yang ketat seperti sekarang ini, perusahaan harus memperhatikan faktor harga, karena besar kecilnya harga yang ditetapkan akan sangat mempengaruhi kemampuan perusahaan dalam bersaing dan juga mampu mempengaruhi konsumen untuk membeli produknya. Adapun fenomena harga yang terjadi dikarenakan harga Sowe Bistro Medan masih terasa mahal sehingga tidak terjangkau oleh daya beli pelanggan yang menyebabkan pelanggan tidak tertarik untuk memesan kembali makanan dan minuman di Sowe Bistro Medan dan harga jual makanan dan minuman belum sesuai dengan rasa yang diinginkan pelanggan sehingga pelanggan tidak memilih Sowe Bistro Medan sebagai pilihan pertama di waktu yang akan datang.

Faktor lain yang mempengaruhi kepuasan pelanggan adalah promosi. Promosi merupakan usaha pemasaran yang memberikan berbagai upaya intensif jangka pendek untuk mendorong keinginan mencoba atau membeli suatu produk atau jasa. Semakin baik promosi maka semakin baik juga kepuasan pelanggan.

Fenomena promosi ini terjadi dikarenakan media promosi seperti instagram belum menunjukkan produk yang lebih fresh dengan tampilan yang berbeda sehingga pelanggan lebih memilih Bens Cafe Griya Medan sebagai pilihan pertama dibandingkan Sowe Bistro Medan dan kurangnya waktu promosi Sowe Bistro Medan menyebabkan pelanggan tidak berani merekomendasikan Sowe Bistro Medan kepada orang lain.

Berdasarkan uraian tersebut maka penulis memilih judul "PENGARUH KUALITAS PELAYANAN, HARGA DAN PROMOSI TERHADAP KEPUASAN PELANGGAN SOWE BISTRO MEDAN".

Berdasarkan uraian di atas, maka dapatlah dirumuskan permasalahan penelitian ini sebagai berikut :

1. Apakah kualitas pelayanan berpengaruh terhadap kepuasan pelanggan Sowe Bistro Medan?

2. Apakah harga berpengaruh terhadap kepuasan pelanggan Sowe Bistro Medan?

3. Apakah promosi berpengaruh terhadap kepuasan pelanggan Sowe Bistro Medan?

4. Apakah kualitas pelayanan, harga dan promosi berpengaruh terhadap kepuasan pelanggan Sowe Bistro Medan?

Berdasarkan rumusan masalah di atas, penelitian ini dilakukan dengan tujuan sebagai berikut :

1. Untuk mengetahui pengaruh kualitas pelayanan terhadap kepuasan pelanggan Sowe Bistro Medan.

2. Untuk mengetahui pengaruh harga terhadap kepuasan pelanggan Sowe Bistro Medan.

3. Untuk mengetahui pengaruh promosi terhadap kepuasan pelanggan Sowe 
Bistro Medan.

4. Untuk mengetahui pengaruh kualitas pelayanan, harga dan promosi terhadap kepuasan pelanggan Sowe Bistro Medan.

\section{KAJIAN LITERATUR}

\section{Kualitas Pelayanan}

Menurut Nasution (2010), "Kualitas pelayanan adalah tingkat keunggulan yang diharapkan dan pengendalian atas tingkat keunggulan tersebut untuk memenuhi keinginan konsumen". Menurut Supranto (2011) "Kualitas pelayanan adalah sebuah kata yang bagi penyedia jasa merupakan sesuatu yang harus dikerjakan dengan baik". Sedangkan menurut Tjiptono (2012), "Kualitas pelayanan adalah tingkat keunggulan yang diharapkan dan pengendalian atas tingkat keunggulan tersebut untuk memenuhi kegatan pelanggan".

Menurut Lupiyoadi (2013), Kualitas pelayanan (jasa) dapat dikelompokkan ke dalam 5 dimensi oleh Parasuraman et.al yaitu

1. Bukti Fisik (Tangible), yaitu : sebagai fasilitas yang dapat dilihat dan di gunakan perusahaan dalam upaya memenuhi kepuasan konsumen.

2. Keandalan (Reliability), yaitu : kemampuan memberikan pelayanan kepada konsumen sesuai dengan yang diharapkan.

3. Daya Tanggap (Responsiveness), yaitu sebagai sikap tanggap, mau mendengarkan dan merespon konsumen dalam upaya memuaskan konsumen.

4. Jaminan (Assurance), yaitu : kemampuan karyawan dalam menimbulkan kepercayaan dan keyakinan konsumen.

5. Empati (Emphaty), yaitu : kemampuan atau kesediaan karyawan memberikan perhatian yang bersifat pribadi.

\section{Harga}

Menurut Sunyoto (2014), "Harga merupakan sejumlah uang yang diberikan pada suatu produk tertentu". Sedangkan menurut Mursid (2014), "Harga merupakan alat utama untuk membedakan produk dari produk saingan". Selanjutnya menurut Assauri (2013), "Harga merupakan satusatunya unsur marketing mix yang menghasilkan penerimaan penjualan, sedangkan unsur lainnya berupa unsur biaya".

Menurut Kotler dan Armstrong (2008), ada empat indikator yang mencirikan harga adalah sebagai berikut :

1. Keterjangkauan Harga

2. Kesesuaian Harga Dengan Kualitas Produk

3. Daya Saing Harga

4. Kesesuaian Harga Dengan Manfaat

\section{Promosi}

Menurut Mursid (2014), "Promosi adalah komunikasi yang persuasif, mengajak, mendesak, membujuk dan meyakinkan". Sedangkan menurut Kotler dan Keller (2009), "Promosi adalah komunikasi pemasaran sarana yang digunakan perusahaan dalam upaya untuk menginformasikan, membujuk dan mengingatkan konsumen langsung ataupun tidak langsung tentang produk dan merek yang mereka jual".

Menurut Tjiptono (2008), "Promosi adalah suatu bentuk komunikasi pemasaran dimana aktivitas pemasaran berusaha menyebarkan informasi, mempengaruhi atau membujuk, mengingatkan pasar sasaran atas perusahaan dan produknya agar bersedia menerima, membeli, dan loyal pada produk yang ditawarkan perusahaan yang bersangkutan".

Menurut Kotler dan Keller (2009), didapat pengukuran promosi yang juga akan digunakan dalam penelitian ini, yaitu :

1. Waktu promosi

2. Tempat promosi

3. Kualitas promosi

4. Media promosi

5. Jangkauan promosi

\section{Kepuasan Pelanggan}

Menurut Canon (2009) menyatakan bahwa "Kepuasan pelanggan adalah respon pelanggan terhadap evaluasi ketidaksesuaian yang dirasakan antara harapan dengan kinerja aktual produk yang dirasakan setelah pemakaian". Sehingga dapat dikatakan bahwa salah satu unsur penting dari setiap 
tugas pelayanan adalah memberikan kepuasan kepada pelanggan dengan menghibur, menyenangkan dan membuat pelanggan gembira dalam segala mungkin hal.

Menurut Rangkuti (2011), kepuasan pelanggan adalah "Respon atau reaksi terhadap ketidaksesuaian antara tingkat kepentingan sebelumnya dan kinerja aktual yang dirasakan setelah penggunaan atau pemakaian". Sedangkan menurut Tjiptono (2012) kepuasan pelanggan adalah "Tingkat perasaan seseorang setelah membandingkan kinerja produk (atau hasil) yang ia rasakan dengan harapannya". Jadi tingkat kepuasan merupakan fungsi dari perbedaan antara kinerja yang dirasakan (perceived performance) dan harapan (expectation).

Menurut Kotler dan Keller (2009 : 140), indikator kepuasan pelanggan adalah :

1. Kesetiaan

2. Membeli ulang

3. Rekomendasi produk kepada orang lain

4. Menunjukkan kekebalan dari perusahaan lain

\section{Kerangka Pemikiran}

Kualitas pelayanan adalah sebuah kata yang bagi penyedia jasa merupakan sesuatu yang harus dikerjakan dengan baik. Semakin tinggi bukti fisik perusahaan maka semakin tinggi kesetiaan pelanggan terhadap

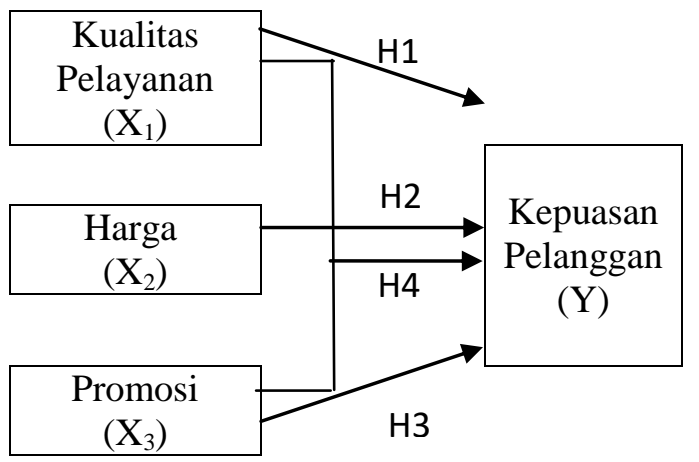

perusahaan. Semakin tinggi kehandalan karyawan menangani keluhan pelanggan maka semakin tinggi pelanggan membeli ulang. Semakin tinggi daya tanggap karyawan maka semakin tinggi juga pelanggan merekomendasikan produk atau jasa kepada orang lain. Semakin tinggi jaminan yang diberikan kepada pelanggan maka semakin tinggi juga konsumen memilih produk dan jasa sebagai pilihan pertama.
Semakin tinggi empati karyawan terhadap pelanggan maka semakin tinggi kesetiaan pelanggan.

Harga merupakan sejumlah uang yang diberikan pada suatu produk tertentu. Harga sangat penting bagi setiap perusahaan. Semakin tinggi keterjangkauan harga maka semakin tinggi kesetiaan pelanggan terhadap perusahaan. Semakin tinggi kesesuaian harga dengan kualitas produk maka semakin tinggi pelanggan membeli ulang. Semakin tinggi daya saing harga maka semakin tinggi juga pelanggan merekomendasikan produk atau jasa kepada orang lain. Semakin tinggi kesesuaian harga dengan manfaat maka semakin tinggi juga konsumen memilih produk dan jasa sebagai pilihan pertama.

Promosi adalah komunikasi pemasaran sarana yang digunakan perusahaan dalam upaya untuk menginformasikan, membujuk dan mengingatkan konsumen langsung ataupun tidak langsung tentang produk dan merek yang mereka jual. Semakin tinggi waktu promosi maka semakin tinggi pelanggan setia terhadap perusahaan. Semakin dekat tempat promosi maka semakin tinggi pelanggan membeli ulang. Semakin tinggi kualitas promosi maka semakin tinggi juga pelanggan merekomendasikan produk atau jasa kepada orang lain. Semakin tinggi media promosi maka semakin tinggi juga konsumen memilih produk dan jasa sebagai pilihan pertama. Semakin tinggi jangkauan promosi maka semakin tinggi kesetiaan pelanggan.

Kepuasan pelanggan adalah respon pelanggan terhadap evaluasi ketidaksesuaian yang dirasakan antara harapan dengan kinerja aktual produk yang dirasakan setelah pemakaian. Penelitian ini kepuasan pelanggan dipengaruhi oleh kualitas pelayanan, harga dan promosi. Hal ini dapat dilihat pada gambar 1 di bawah ini.

\section{Gambar 1 Kerangka Pemikiran}

\section{Hipotesis Penelitian}

Hipotesis penelitian ini adalah sebagai berikut :

Mahmoud (2015), hasil pengujian ini menunjukkan bahwa kualitas layanan mempunyai pengaruh terhadap kepuasan pelanggan. Artinya variabel kualitas layanan 
menjadi salah satu hal penting yang dinilai konsumen ketika menggunakan. Apabila kualitas layanan yang diberikan perusahaan meningkat, itu akan meningkatkan tingkat kepuasan konsumen. Hasil ini mendukung penelitian sebelumnya yaitu Jusoff (2013), Bucak (2014), Al-Tit (2015), Imam (2015) dan Quyet (2015).

$\mathrm{H}_{1}$ : Kualitas pelayanan berpengaruh terhadap kepuasan pelanggan Sowe Bistro Medan.

Ehsani (2015), Hasil pengujian ini menunjukkan bahwa harga mempunyai pengaruh terhadap kepuasan pelanggan. Artinya variabel harga merupakan hal yang penting bagi kegiatan pemasaran. Apabila harga yang diberikan perusahaan rendah, itu akan meningkatkan tingkat kepuasan konsumen. Hasil ini mendukung penelitian sebelumnya yaitu Herrmann (2015), Niharika (2015), Ahmed (2015), Nazari (2015), Gupta (2014), Oghojafor (2014), Alelign (2014) dan Jusoff (2013).

$\mathrm{H}_{2}$ : Harga berpengaruh terhadap kepuasan pelanggan Sowe Bistro Medan.

Alelign (2014), Hasil pengujian ini menunjukkan bahwa promosi mempunyai pengaruh terhadap kepuasan pelanggan. Artinya variabel promosi menjadi salah satu hal yang dinilai konsumen. Apabila promosi yang diberikan perusahaan meningkat, itu akan meningkatkan kepuasan konsumen. Hasil ini mendukung penelitian sebelumnya yaitu Niharika (2015), Ahmed (2015) dan Oghojafor (2014).

$\mathrm{H}_{3}$ : Promosi berpengaruh terhadap kepuasan pelanggan Sowe Bistro Medan.

Hasil pengujian secara umum, dapat dilihat bahwa ketiga variabel bebas yaitu kualitas pelayanan, harga dan promosi secara bersama-sama (simultan) berpengaruh terhadap kepuasan pelanggan. Apabila terjadi kenaikan tingkat kualitas pelayanan, harga dan promosi, maka tingkat kepuasan pelanggan akan meningkat, dan hal ini dapat menopang tingkat kepercayaan konsumen.

$\mathrm{H}_{4}$ : Kualitas pelayanan, harga dan promosi berpengaruh terhadap kepuasan pelanggan Sowe Bistro Medan.

\section{METODE PENELITIAN}

\section{Metode Yang Digunakan}

Penelitian ini menggunakan metode penelitian deskriptif kuantitatif dimana metode penelitian ini bertujuan untuk menggambarkan tentang karakteristik dari suatu keadaan atau objek penelitian yang dilakukan melalui pengumpulan dan analisis data kuantitatif serta pengujian statistik dengan software SPSS.

\section{Operasional Variabel Penelitian}

Variabel penelitian ini terdiri dari dua macam variabel, yaitu variabel terikat (dependent variable) atau variabel yang tergantung pada variabel lainnya, serta variabel bebas (independent variable) atau variabel yang tidak tergantung pada variabel yang lainnya. Variabel - variabel yang digunakan pada penelitian ini adalah :

1. Variabel bebas atau independen, yaitu variabel yang mempengaruhi variabel lain. Dalam penelitian ini variabel independen meliputi : kualitas pelayanan, harga dan promosi.

2. Variabel terikat atau dependen, yaitu variabel yang dipengaruhi oleh variabel lain. Dalam penelitian ini variabel dependen adalah kepuasan pelanggan.

\section{Populasi dan Sampel}

Yang menjadi populasi adalah pelanggan yang datang ke Sowe Bistro Medan selama dari bulan Januari 2016 sampai dengan Maret 2016 yang berjumlah 5.274 orang. Teknik pengambilan sampel yang digunakan dalam penelitian ini adalah Simple Random Sampling. sehingga sampel pada penelitian ini berjumlah 99 responden.

\section{Uji Validitas dan Reliabilitas}

Uji validitas dilakukan untuk mengukur apakah data yang telah didapat setelah penelitian merupakan data yang valid dengan alat ukur digunakan yaitu daftar pertanyaan (kuesioner). Kuisioner dinyatakan valid apabila $\mathrm{r}$ hitung lebih besar dari 0,30.

Uji reliabilitas digunakan untuk melihat apakah alat ukur yang digunakan (kuesioner) menunjukkan konsistensi didalam mengukur gejala yang sama. Kuesioner dinyatakan reliabel apabila memiliki kehandalan atau nilai alpha sebesar 
0,60 atau lebih. Alat bantu yang digunakan untuk mengolah data dalam penelitian ini adalah program SPSS.

\section{Analisis Regresi Linear Berganda}

Analisis Regresi Linear Berganda adalah analisis yang digunakan untuk menyajikan data dalam bentuk angka. Analisis ini menggunakan model regresi linear berganda. Rumus regresi linear berganda adalah sebagai berikut :

$\mathrm{Y}=\mathrm{a}+\mathrm{b}_{1} \mathrm{X}_{1}+\mathrm{b}_{2} \mathrm{X}_{2}+\mathrm{b}_{3} \mathrm{X}_{3}+\mathrm{e}$

Keterangan :

Y : kepuasan pelanggan

a : konstanta

e : Standar Error

$\mathrm{X}_{1} \quad$ : kualitas pelayanan

$\mathrm{X}_{2} \quad$ : harga

$\mathrm{X}_{2} \quad$ : promosi

$b_{1}, b_{2}, b_{3}$ : koefisien regresi

\section{Pengujian Hipotesis}

Proses selanjutnya adalah melakukan pembuktian hipotesis yang diajukan dengan perhitungan menggunakan alat bantu program SPSS (Statistic Product and Service Solution) dengan analisis menggunakan:

1. Uji -t (parsial)

Uji -t yaitu menguji apakah variabel bebas mempunyai pengaruh signifikan terhadap nilai variabel terikat

\section{Uji-F (Serempak)}

Uji f digunakan untuk melihat secara bersama-sama pengaruh secara positif dan signifikan dari variabel bebas $(\mathrm{X})$ terhadap variabel terikat $(\mathrm{Y})$

3. Koefisien Determinasi $\left(\mathrm{R}^{2}\right)$

Determinasi digunakan untuk melihat seberapa besar kontribusi variabel bebas terhadap variabel terikat.

\section{HASIL PENELITIAN DAN PEMBAHASAN}

\section{Analisis Regresi Linear Berganda}

Analisis regresi linier berganda digunakan dalam penelitian ini dengan tujuan untuk membuktikan hipotesis mengenai pengaruh kualitas pelayanan, harga dan promosi terhadap kepuasan pelanggan Sowe Bistro Medan. Model persamaan regresi yang dapat dituliskan dari hasil SPSS dalam bentuk persamaan regresi standardized adalah sebagai berikut :

$$
\begin{aligned}
& \mathrm{Y}=4,689+0,406 \mathrm{X}_{1}-0,159 \mathrm{X}_{2}+0,291 \mathrm{X}_{3} \\
& \text { Model persamaan regresi linear } \\
& \text { berganda dapat dijelaskan : }
\end{aligned}
$$

1. Konstanta (a) sebesar 4,689 yang berarti apabila variabel bebas yaitu kualitas pelayanan, harga dan promosi dianggap nol maka nilai kepuasan pelanggan yang dianggap $\mathrm{Y}$ mengalami penambahan sebesar 4,689 satuan.

2. Koefisien regresi $\left(b_{1}\right)$ sebesar 0,406 menunjukkan kualitas pelayanan memiliki koefisien positif terhadap kepuasan pelanggan. Hal ini berarti apabila kualitas pelayanan $\left(\mathrm{X}_{1}\right)$ dinaikkan satu satuan maka perubahan nilai kepuasan pelanggan (Y) akan bertambah sebesar 0,406 satuan dengan asumsi variabel bebas lainnya dianggap nol.

3. Koefisien regresi $\left(b_{2}\right)$ sebesar $-0,159$ menunjukkan harga memiliki koefisien positif terhadap kepuasan pelanggan. Hal ini berarti apabila harga $\left(X_{1}\right)$ dinaikkan satu satuan maka perubahan nilai kepuasan pelanggan (Y) akan berkurang sebesar 0,159 satuan dengan asumsi variabel bebas lainnya dianggap nol.

4. Koefisien regresi $\left(b_{3}\right)$ sebesar 0,291 menunjukkan promosi memiliki koefisien positif terhadap kepuasan pelanggan. Hal ini berarti apabila promosi $\left(\mathrm{X}_{1}\right)$ dinaikkan satu satuan maka perubahan nilai kepuasan pelanggan (Y) akan bertambah sebesar 0,291 satuan dengan asumsi variabel bebas lainnya dianggap nol.

\section{Pengujian Hipotesis}

1. Uji Secara Parsial

Uji -t bertujuan untuk menguji apakah variabel bebas mempunyai pengaruh signifikan terhadap nilai variabel terikat. Berdasarkan hasil SPSS dapat diketahui $t_{\text {tabel }}$ sebesar 1,985 dengan rumus pengambilan $\mathrm{t}_{\text {tabel }}$ yaitu $\mathrm{df}=\mathrm{n}-\mathrm{k}-1=95$ dengan taraf signifikansi 0,05 . Hasil pengujian hipotesis 1 untuk variabel kualitas pelayanan terhadap kepuasan pelanggan menunjukkan nilai $t_{\text {hitung }}$ sebesar 5,673 dengan signifikansi 0,000 . Dengan menggunakan $\mathrm{t}_{\text {tabel }}$ sebesar 1,985 dan 
batas signifikansi 0,05 , maka diperoleh hasil hipotesis nilai $\mathrm{t}_{\text {hitung }}$ lebih besar dari 1,985 dan nilai signifikansi lebih kecil dari 0,05 yang menyatakan bahwa kualitas pelayanan berpengaruh terhadap kepuasan pelanggan Sowe Bistro Medan.

Hasil pengujian hipotesis 2 untuk variabel harga terhadap kepuasan pelanggan menunjukkan nilai $t_{\text {hitung }}$ sebesar 2,220 dengan signifikansi 0,029. Dengan menggunakan $t_{\text {tabel }}$ sebesar 1,985 dan batas signifikansi 0,05 , maka diperoleh hasil hipotesis nilai $\mathrm{t}_{\text {hitung }}$ lebih besar dari 1,985 dan nilai signifikansi lebih kecil dari 0,05 yang menyatakan bahwa harga berpengaruh terhadap kepuasan pelanggan Sowe Bistro Medan.

Hasil pengujian hipotesis 3 untuk variabel promosi terhadap kepuasan pelanggan menunjukkan nilai $t_{\text {hitung }}$ sebesar 4,331 dengan signifikansi 0,000. Dengan menggunakan $t_{\text {tabel }}$ sebesar 1,985 dan batas signifikansi 0,05 , maka diperoleh hasil hipotesis nilai $t_{\text {hitung }}$ lebih besar dari 1,985 dan nilai signifikansi lebih kecil dari 0,05 yang menyatakan bahwa promosi berpengaruh terhadap kepuasan pelanggan Sowe Bistro Medan.

\section{Uji Secara Simultan}

Uji - F (uji secara simultan) bertujuan menunjukkan apakah semua variabel yang dimasukkan dalam model mempunyai pengaruh secara bersama-sama terhadap variabel terikat. Hasil SPSS menunjukkan nilai $F_{\text {hitung }}$ sebesar 55,768 dengan tingkat signifikan sebesar 0.000 . Nilai $F_{\text {tabel }}$ pada penelitian ini dicari pada tabel $\mathrm{F}$ dengan df1 $=3$ dan df $2=95$ sehingga diperoleh nilai $F_{\text {tabel }}$ sebesar 2,70 dengan hasil tersebut dimana $F_{\text {hitung }}>F_{\text {tabel }}$ dan nilai signifikan yang lebih kecil dari pada alpha 5\% maka kesimpulan yang dapat diambil bahwa secara simultan kualitas pelayanan, harga dan promosi berpengaruh terhadap kepuasan pelanggan Sowe Bistro Medan.

\section{Koefisien Determinasi $\left(\mathbf{R}^{2}\right)$}

Koefisien determinasi ini digunakan untuk mengetahui seberapa besar pengaruh variabel-variabel bebas memiliki pengaruh terhadap variabel terikatnya. Nilai koefisien determinasi ditentukan dengan nilai adjusted $R$ square. Simbol Adjusted $R$ Square merupakan nilai koefisien determinasi yang telah dikoreksi berdasarkan jumlah variabel. Berdasarkan hasil SPSS diperoleh nilai koefisien determinasi sebesar 0,626. Hal ini menunjukkan bahwa kemampuan variabel kualitas pelayanan, harga dan promosi menjelaskan pengaruhnya terhadap variabel kepuasan pelanggan sebesar $62,6 \%$. Sedangkan sisanya sebesar $37,4 \%$ merupakan variabel bebas lain yang tidak diteliti dalam penelitian ini seperti periklanan, lokasi dan merek.

\section{Pembahasan Hasil Penelitian}

Hasil pengujian hipotesis 1 diperoleh nilai $\mathrm{t}_{\text {hitung }}$ sebesar 5,673 lebih besar dari 1,985 dan nilai signifikansi sebesar 0,000 lebih kecil dari 0,05 yang menyatakan bahwa kualitas pelayanan berpengaruh terhadap kepuasan pelanggan Sowe Bistro Medan. Hasil ini sejalan dengan penelitian sebelumnya yaitu Mahmoud (2015), Jusoff (2013), Bucak (2014), Al-Tit (2015), Imam (2015) dan Quyet (2015) yang menyatakan bahwa kualitas pelayanan berpengaruh terhadap kepuasan pelanggan.

Hasil pengujian hipotesis 2 diperoleh nilai $t_{\text {hitung }}$ sebesar 2,220 lebih besar dari 1,985 dan nilai signifikansi sebesar 0,029 lebih kecil dari 0,05 yang menyatakan bahwa harga berpengaruh terhadap kepuasan pelanggan Sowe Bistro Medan. Hasil ini sejalan dengan penelitian sebelumnya yaitu Ehsani (2015), Herrmann (2015), Niharika (2015), Ahmed (2015), Nazari (2015), Gupta (2014), Oghojafor (2014), Alelign (2014) dan Jusoff (2013) yang menyatakan harga berpengaruh terhadap kepuasan pelanggan.

Hasil pengujian hipotesis 3 diperoleh nilai $\mathrm{t}_{\text {hitung }}$ sebesar 4,331 lebih besar dari 1,985 dan nilai signifikansi sebesar 0,0003 lebih kecil dari 0,05 yang menyatakan bahwa promosi berpengaruh terhadap kepuasan pelanggan Sowe Bistro Medan. Hasil ini sejalan dengan penelitian sebelumnya yaitu Alelign (2014), Niharika (2015), Ahmed (2015) dan Oghojafor (2014) yang menyatakan bahwa promosi berpengaruh terhadap kepuasan pelanggan.

Variabel yang dominan mempengaruhi kepuasan pelanggan adalah variabel kualitas 
pelayanan. Hal ini dikarenakan nilai koefisien regresi variabel kualitas pelayanan sebesar 0,406 lebih besar dari nilai koefisien regresi variabel harga sebesar $-0,159$ dan nilai koefisien regresi variabel promosi sebesar 0,291.

Hasil pengujian hipotesis 4 untuk diperoleh nilai $F_{\text {hitung }}$ diperoleh nilai $F_{\text {hitung }}$ sebesar 55,768 lebih besar dari $F_{\text {tabel }}$ sebesr 2,70 dan nilai signifikan sebesar 0,000 lebih kecil dari pada alpha 5\% maka kesimpulan yang dapat diambil bahwa secara simultan kualitas pelayanan, harga dan promosi berpengaruh terhadap kepuasan pelanggan Sowe Bistro Medan. Hal ini dapat diperkuat dengan koefisien determinasi sebesar 0,626. Hal ini menunjukkan bahwa kemampuan variabel kualitas pelayanan, harga dan promosi menjelaskan pengaruhnya terhadap variabel kepuasan pelanggan sebesar $62,6 \%$. Sedangkan sisanya sebesar $37,4 \%$ merupakan variabel bebas lain yang tidak diteliti dalam penelitian ini seperti periklanan, lokasi dan merek.

\section{KESIMPULAN}

\section{Kesimpulan}

Berdasarkan hasil penelitian maka peneliti dapat memberikan beberapa kesimpulan antara lain:

1. Secara parsial, kualitas pelayanan berpengaruh terhadap kepuasan pelanggan Sowe Bistro Medan.

2. Secara parsial, harga berpengaruh terhadap kepuasan pelanggan Sowe Bistro Medan.

3. Secara parsial, promosi berpengaruh terhadap kepuasan pelanggan Sowe Bistro Medan.

4. Secara simultan, bahwa kualitas pelayanan, harga dan promosi berpengaruh terhadap kepuasan pelanggan Sowe Bistro Medan.

5. Besarnya koefisien determinasi dapat dilihat pada Adjusted $R$ Square yaitu kemampuan variabel kualitas pelayanan, harga dan promosi menjelaskan pengaruhnya terhadap variabel kepuasan pelanggan sebesar $79,2 \%$. Sedangkan sisanya sebesar 20,8\% merupakan variabel bebas lain yang tidak diteliti dalam penelitian ini seperti periklanan, lokasi dan merek.

\section{REFERENSI}

Al-Tit, Ahmad A. 2015. The Effect of Service and Food Quality on Customer Satisfaction and Hence Customer Retention. Arab Saudi : Qassim University.

Alelign, Dereje. 2014. The Impact of Marketing Mix on Customer Satisfaction-A Case of MOHA Soft Drinks Industry S.C, Hawassa Millennium Plant. Ethiopia : Hawassa University.

Assauri, Sofjan. 2013. Manajemen Pemasaran. Jakarta : Penerbit Rajawali Press.

Ahmed, Selim. 2015. The Effects Of Marketing Mix On Consumer Satisfaction: A Literature Review From Islamic Perspectives. Malaysia : International Islamic University Malaysia.

Bucak, Turgay. 2014. The Effect of Service Quality on Customer Satisfaction : A Research on Hotel Businesses. Turkey : Çanakkale Onsekiz Mart University

Canon, Joseph P. , Et. Al. 2009. Pemasaran Dasar. Diterjemahkan oleh Afia R. Fitriati dan Ria Cahyani. Jakarta : Penerbit Salemba Empat.

Ehsani, Zahra. 2015. Effect Of Quality And Price On Customer Satisfaction And Commitment In Iran Auto Industry. Iran : Khatam University

Gupta, Punkaj. 2014. Impact of Price sensitivity on Customer Satisfaction: An Empirical Study in Retail Sector. India : University of Jammu.

Herrmann, Andreas. 2015. The Influence of Price Fairness on Customer Satisfaction: an Empirical Test in the Context of Automobile Purchases. Switzerland : University of St Gallen, St Gallen. 
Imam, Abeer. 2015. Impact Of Service Quality On Customer Satisfaction Of Banking Sector Employees: A Study Of Lahore, Punjab. Pakistan : COMSATS Institute of Information Technology, Lahore.

Jusoff, Kamaruzaman. 2013. The Effect of Service Quality and Price on Satisfaction and Loyalty of Customer of Commercial Flight Service Industry. Malaysia : Universiti Putra Malaysia

Kotler, Philip and Amstrong, Gary. 2008. Prinsip-Prinsip Dasar Manajemen Pemasaran. Edisi 13. Diterjemahkan oleh Teguh, Hendra, Ronny A. Rusli, dan Benjamin Molan. Jakarta: Penerbit Erlangga

Kotler, Philip and Kevin Keller. 2009. Manajemen Pemasaran. Edisi 13. Diterjemahkan oleh Teguh, Hendra, Ronny A. Rusli, dan Benjamin Molan. Jakarta: Penerbit Erlangga.

Lupiyoadi, Rambat. 2013. Manajemen Pemasaran Jasa. Jakarta : Penerbit Salemba Empat.

Mahmoud, Abdel Fattah. 2015. The Impact of Service Quality Dimensions on Customer Satisfaction: A Field Study of Arab Bank in Irbid City, Jordan. Jordan : Zarqa University.

Mursid. 2014. Manajemen Pemasaran. Jakarta : Penerbit Bumi Aksara.

Nazari, Mohsen. 2015. Impact of Price fairness on Price Satisfaction, Customer satisfaction and Customer Loyalty in Iran Telecommunication Market (Case: MTN Irancell Company). Iran : University of Tehran

Nasution, M.N. 2010. Manajemen Mutu Terpadu: Total Quality Management (Edisi 2). Jakarta : Penerbit Ghalia Indonesia.

Niharika. 2015. Effect Of Marketing Mix On Customer Satisfaction. India : Hisar
University

Oghojafor, B.E. Akpoyomare. 2014. Determinants Of Customer Satisfaction And Loyalty In The Nigerian Telecommunications Industry. Nigeria : University of Lagos

Quyet, Tran Van. 2015. Service Quality Effects on Customer Satisfaction in Banking Industry. Vietnam : Thai Nguyen University of Economic and Business Administration.

Rangkuti, Freddy. 2011. Strategi Promosi yang Kreatif. Jakarta : PT. Gramedia Pustaka Utama.

Supranto. 2011. Pengukuran Tingkat Kepuasan Pelanggan. Cetakan Ketiga. Jakarta : Penerbit Rineka Cipta.

Sunyoto, Danang. 2014. Dasar-Dasar Manajemen Pemasaran. Yogyakarta : Penerbit CAPS.

Tjiptono, Fandi. 2008. Strategi Pemasaran. Yogyakarta : Penerbit ANDI.

2012. Pemasaran Jasa. Malang: Penerbit Bayumedia Publising. 
